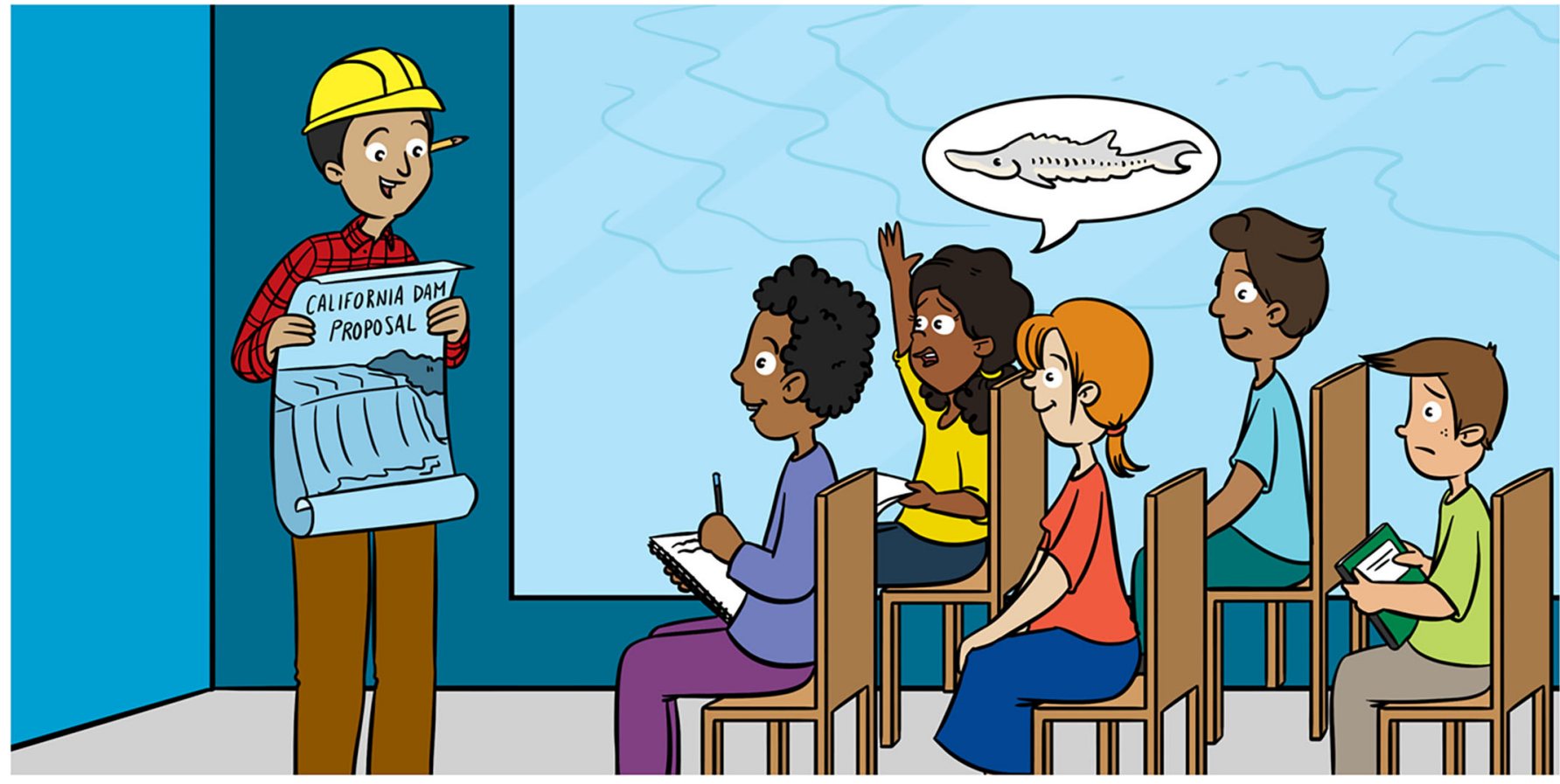

\title{
LIVING FOSSILS: STURGEON OF THE SAN FRANCISCO ESTUARY
}

\section{Page E. Vick ${ }^{1^{*}}$ and John T. Kelly ${ }^{2^{*}}$}

${ }^{1}$ California Central Valley Office, National Marine Fisheries Service, National Oceanic and Atmospheric Administration, Sacramento, CA, United States

${ }^{2}$ California Department of Fish and Wildlife, Fisheries Branch, Sacramento, CA, United States

YOUNG REVIEWERS

CORTE

MADERA

SCHOOL

AGES: $10-11$
Sturgeon are fish that are considered living fossils. Their ancestors date back over 200 million years, to the same time as dinosaurs. These fish can grow taller than humans (over $2 \mathrm{~m}$ ), weigh over $160 \mathrm{~kg}$, and live as long as humans. Sturgeon species have special adaptations, such as a vacuum-like mouth and body armor called scutes. There are 27 species of sturgeon worldwide. Two species, green and white sturgeon, are native to California, USA, and are some of the largest animals in San Francisco Bay. Sturgeon populations have declined due to habitat loss, water management, overfishing, poaching, pollution, and climate change. Sturgeon cannot jump over barriers like salmon can, so structures like dams that block water also block sturgeon from reaching their natural spawning habitat farther upstream in the river. Scientists are using new technologies to monitor sturgeon populations and discover the unique behaviors of these dinosaur-era fish in California's rivers and estuaries. 
SPAWN

To reproduce. Fish release eggs and sperm into the water for fertilization.

\section{ESTUARY}

Final section of rivers where the water from rivers mixes with water from the ocean.

\section{THREATENED}

\section{SPECIES}

A species that is likely to become endangered and is protected by the U.S. Endangered Species Act of 1973.

\section{BARBELS}

A slender, whisker-like sensory organ near the mouth of some fish. Taste buds and touch receptors on the barbels are used to find prey.

\section{ANCIENT FISH IN A MODERN WORLD}

Sturgeon ancestors have been around for more than 200 million years-long before dinosaurs like T-Rex! These fish are large (over $2 \mathrm{~m})$, long-lived (70-100 years), and will spawn (reproduce) many times during their lives. However, they are late to mature and only spawn every 2-6 years, which means it takes many years for sturgeon populations to grow. Two species of sturgeon, called green sturgeon and white sturgeon, are found within California waters (Figure 1), especially in the San Francisco Estuary (called the Estuary for short) [1]. The Estuary is very important for both of these species throughout their long lives. Sturgeons are among the largest animals living in the Estuary. These gentle and toothless giants spend most of their time slowly feeding on some of the smallest animals. In the past, sturgeon were common in the Estuary, but because of overfishing, habitat loss, and other threats, there are now far fewer sturgeon living in the Estuary. To prevent populations from further decline, these fish have special protections. Green sturgeon in the Estuary are a threatened species, meaning they are protected in the United States by a law called the Endangered Species Act. California and other states protect white sturgeon with laws that limit fishing by size, to protect the youngest and oldest fish [2]. In this article, we will look at what makes sturgeon such unique animals and explore ways we can all work to protect them.

\section{LIVING FOSSILS}

Sturgeon are called living fossils because they have changed very little over time. Fish you would recognize as sturgeon first appear in the fossil record during the Triassic period (245-208 million years ago) and their appearance has not changed much since then. However, the fish that sturgeon evolved from are very different from the sturgeon we see today. A major difference is the sturgeon's skeleton. Sturgeon ancestors had skeletons composed of bone, like the human skeleton. But, over time, the material of the sturgeon skeleton changed from bone to cartilage, like your nose and ears. Although most of the sturgeon skeleton is made of cartilage, sturgeon do have some bones in their bodies. Parts of the skull and pectoral fins are bone, and they have bony plates on their skin called scutes. Scutes act as armor. Sturgeon have five rows of scutes that run along their bodies. Details of sturgeon anatomy are shown in Figure 2.

At first glance, many people may mistake a sturgeon for a shark, due to its cigar-shaped body and shark-like tail. However, rather than mouths full of sharp teeth like sharks, sturgeon have toothless, tube-like mouths. Both sturgeon and sharks have ampullae of Lorenzini and all sturgeon and many sharks have barbels. Ampullae of Lorenzini are gel-filled pores on the underside of the head that detect electrical signals given off by other living animals in the water and mud. Barbels 
Figure 1

$(\mathbf{a}, \mathbf{b})$ Green sturgeon are olive to dark green with a yellowish green-white belly. They have green stripes on their sides and belly, a pointed snout with barbels midway between the tip of the snout and mouth, and 8-11 sharp dorsal scutes. They can grow to about $3 \mathrm{~m}$ in length. $(\mathbf{c}, \mathbf{d})$ White sturgeon are gray with a solid white belly. They have a blunted snout with barbels closer to their snout than mouth, and 11-14 dull dorsal scutes. They are the largest fish in North America and can grow to 6 meters.
PROTRUSIBLE JAW

Specialized jaw that allows for the fish to extend or withdraw its mouth.
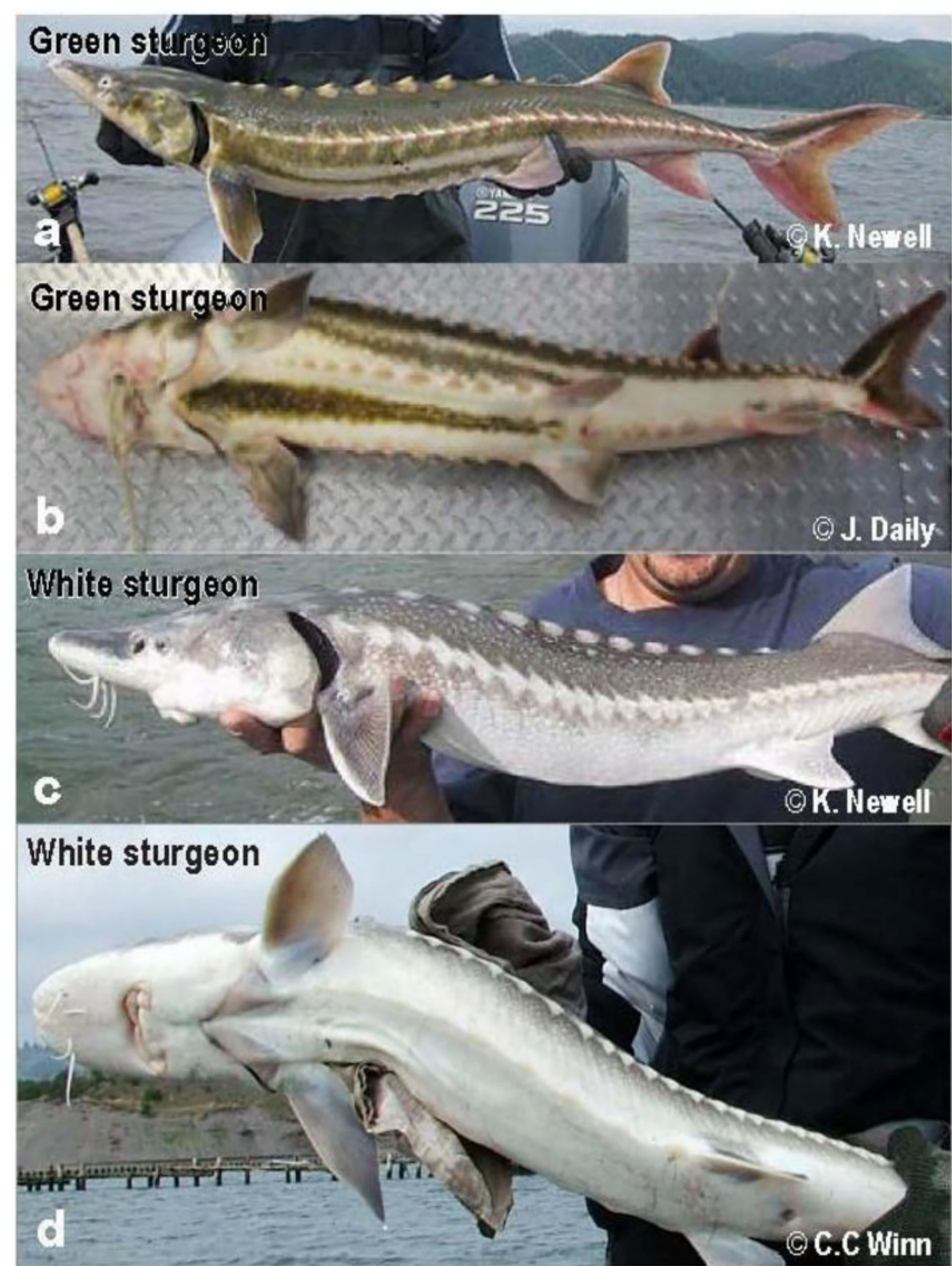

Figure 1

are whisker-like sensory organs, similar to human taste buds, that are used to taste for prey. Sturgeon and sharks share other similar features, but they are not closely related.

\section{LIFE IN THE ESTUARY}

Since sturgeon have poor vision and live in murky waters, they use their barbels and ampullae of Lorenzini to find animals buried within the seafloor. They slurp up their prey by stretching out their protrusible jaw a few centimeters to reach the seafloor. When they find food, they suck it up like a vacuum cleaner and crush it in their mouths. The Estuary is home to the many prey that sturgeon eat, such as shrimp, 
Figure 2

Sturgeon anatomy. The lower photos show the location of the ampullae of Lorenzini (small pores that detect electrical signals) and the protrusible jaw that allows them to slurp up their prey.

\section{Figure 3}

Sturgeon life cycle. Arrows show transitions to new life stages and indicate whether the habitat for each life stage contains freshwater, brackish water, or salt water.

\section{BRACKISH}

Slightly salty water in estuaries that comes from the mixture of river water and ocean water.

\section{ANADROMOUS}

Fish that live most of their lives in the ocean and return to rivers to spawn.
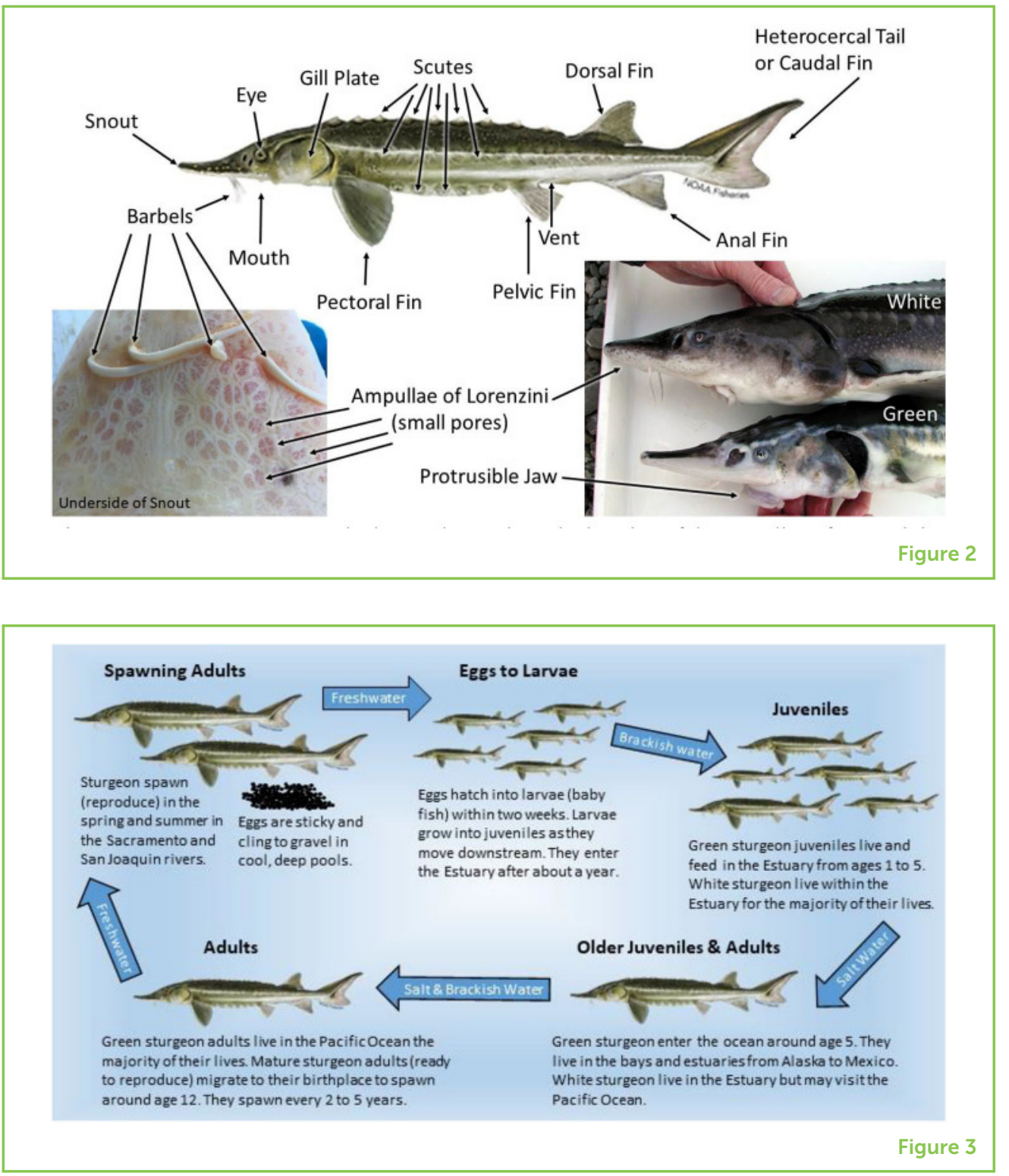

clams, and small fishes. Adults and juveniles of both species feed within the brackish (partly salty) water of the Estuary [1].

All fish need a specific balance of water and salts in their bodies to stay alive. Fish in the ocean are surrounded by too much salt, while fish in freshwater are surrounded by water that has almost no salt. Fish have evolved many ways to move salt and water into or out of their bodies to maintain the right balance, but most specialize in just one habitat throughout their lives [3]. Unlike most fishes, green and white sturgeon can live in freshwater, brackish water, and saltwater (Figure 3). Green sturgeon are anadromous, meaning that adults travel to spawn in freshwater, but spend most of their adult lives in oceans and estuaries. White sturgeon are semi-anadromous, meaning that they spawn in freshwater and may spend some time in saltwater, but most of their adult lives are spent in brackish water. 


\section{STURGEON LIFE CYCLE}

Sturgeon can spawn several times throughout their lives. Green sturgeon live up to 70 years and are able to reproduce around age 15. White sturgeon live up to 100 years and are able to reproduce around age 12. When they are mature, both species return to their birthplaces to spawn, traveling from 100 to more than 1,600 km [1]! Sturgeon have homing abilities that they use to navigate their way home to spawn. The water in each spawning river has a recognizable scent that sturgeon can detect, so they mostly rely on their sense of smell to find the way home [4].

In California's Central Valley, green sturgeon only spawn in the Sacramento River and a few of the smaller rivers that flow into it, while white sturgeon spawn in both the Sacramento and San Joaquin rivers [1]. In the Sacramento River, green sturgeon spawn further north than white sturgeon. Most green sturgeon spawn from April to July, while most white sturgeon spawn from February to May. Sturgeon spawn in deep pockets of the river ( $4.5 \mathrm{~m}$ or deeper) with gravel and large rocks. The fertilized eggs are sticky and glue themselves to the rocks until they hatch into 1-cm larvae. Larvae grow into juveniles, and after about a year spent moving down the river, the juveniles enter the Estuary. Green sturgeon juveniles remain in the Estuary for up to 5 years before they leave for the Pacific Ocean. Green sturgeon adults move in and out of coastal estuaries and bays to feed and grow. White sturgeon usually live in the Estuary for most of their lives. Some may make short journeys into the Pacific Ocean [1].

\section{FOOD WEB}

All feeding relationships, or food chains, within the ecosystem

\section{WHY ARE STURGEON IMPORTANT?}

Sturgeon are part of the native ecosystems and food webs in California. They are important predators of many small animals. Young, small sturgeon are also food for larger predators. Large adult sturgeon do not have many natural predators, but some are eaten by marine mammals, like California sea lions, and large sharks. Like salmon, sturgeon bring nutrients from saltwater into freshwater environments. Marine nutrients are taken in by sturgeon when they eat prey in the ocean or the brackish Estuary. The nutrients are released into the freshwater environment when sturgeon poop, spawn, or die [5]. Many inland organisms, including trees, smaller plants, insects, and other animals, benefit from ecosystems rich in marine nutrients.

\section{WHAT THREATENS STURGEON POPULATIONS?}

Sturgeon population decline is primarily due to overfishing and habitat loss. Because sturgeon take many years to mature, individuals need to survive long enough to reproduce. Sturgeon are prized for their meat and for their eggs, which can be turned into caviar. Sturgeon 
were overfished (too many fish were removed from the Estuary), and all commercial sturgeon fishing was banned on the west coast of the United States to protect sturgeon populations [2].

Sturgeon have lost access to their habitat because of human activities. Large-scale farming and city development have reduced the amount and quality of sturgeon habitat. These activities not only directly remove habitat but also increase pollution in the environment. Barriers like dams also block sturgeon from reaching the best spawning habitats [2]. Some barriers have been removed, but sturgeon still have limited access to these spawning habitats. Before sturgeon populations can recover, these barriers must be removed or appropriate sturgeon passages must be built.

1 http://go.usa.gov/ xvSRn

2 https://www.fisheries. noaa.gov/species/ green-sturgeon

3 wildlife.ca.gov/ Regulations

\section{HOW CAN WE HELP STURGEON?}

Scientists in California study sturgeon in nature and in labs to better understand and protect these species. Scientists catch and tag sturgeon to understand their growth, spawning behavior, and habitat use. In lab studies, scientists run experiments on sturgeon of all life stages, to understand their swimming abilities. Scientists work together on projects that will benefit sturgeon and help the species to recover.

There are several easy ways that you can help sturgeon, too ${ }^{1}$. First, conserve water while washing dishes, bathing, and brushing your teeth. Also, keep dangerous chemicals out of your home and our waterways by making your own household cleaners or purchasing cleaners that are labeled non-toxic. Look for the Safer Choice label if you are in the United States. Properly dispose of trash, old paints and chemicals, and recyclables in special facilities, so that they do not end up polluting the environment. You can also continue to learn about sturgeon, their habitat, and species conservation ${ }^{2}$. If you live in California and fish for white sturgeon, follow all fishing regulations ${ }^{3}$ and report any sturgeon catch. Fishing for green sturgeon is not allowed. If a green sturgeon is caught, it must be released without being removed from the water. Combined, the research performed by scientists and the actions that we all take in our daily lives can help to preserve these living fossils for many more years to come.

\section{REFERENCES}

1. Heublein, J., Bellmer, R., Chase, R. D., Doukakis, P., Gingras, M., Hampton, D., et al. 2017. Life History and Current Monitoring Inventory of San Francisco Estuary Sturgeon. Santa Cruz, CA: U.S. Department of Commerce, National Oceanic and Atmospheric Administration, National Marine Fisheries Service, Southwest Fisheries Science Center. 
2. National Oceanic and Atmospheric Administration. 2018 Recovery Plan for the southern Distinct Population Segment of the North American Green Sturgeon (Acipenser medirostris). National Oceanic and Atmospheric Administration.

3. Morais, P., and Dias, E. 2021. Estuaries, a happy place for fish. Front Young Minds. 9:613862. doi: 10.3389/frym.2021.613862

4. Ueda, H. 2012. Physiological mechanisms of imprinting and homing migration in Pacific salmon Oncorhynchus spp. J Fish Biol. 81:543-58. doi: 10.1111/j.10958649.2012.03354.x

5. Naiman, R. J., Bilby, R. E., Schindler, D. E., and Helfield, J. M. 2002. Pacific salmon, nutrients, and the dynamics of freshwater and riparian ecosystems. Ecosystems 5:399-417. doi: 10.1007/s10021-001-0083-3

SUBMITTED: 01 October 2020; ACCEPTED: 02 September 2021; PUBLISHED ONLINE: 07 October 2021.

EDITED BY: Peggy W. Lehman, California Department of Water Resources, United States

CITATION: Vick PE and Kelly JT (2021) Living Fossils: Sturgeon of the San Francisco Estuary. Front. Young Minds 9:612877. doi: 10.3389/frym.2021.612877

CONFLICT OF INTEREST: The authors declare that the research was conducted in the absence of any commercial or financial relationships that could be construed as a potential conflict of interest.

COPYRIGHT @ 2021 Vick and Kelly. This is an open-access article distributed under the terms of the Creative Commons Attribution License (CC BY). The use, distribution or reproduction in other forums is permitted, provided the original author(s) and the copyright owner(s) are credited and that the original publication in this journal is cited, in accordance with accepted academic practice. No use, distribution or reproduction is permitted which does not comply with these terms.

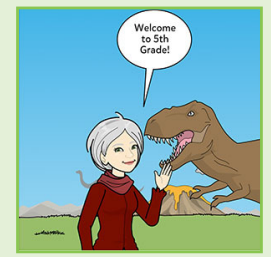

\section{YOUNG REVIEWERS}

\section{CORTE MADERA SCHOOL, AGES: 10-11}

We are a fifth grade class, excited about all things science. Since we live in the San Francisco Bay Area, we love to learn about the amazing wildlife and the natural environment around us.

\section{AUTHORS}

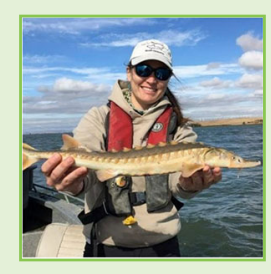

\section{PAGE E. VICK}

Page Vick, M.S., NOAA Fisheries. I am Fish Biologist in the California Central Valley Office at National Oceanic and Atmospheric Administration Fisheries in Sacramento, California. I work to protect and restore green sturgeon and their habitat in California. As a master's degree student at the University of Southern Mississippi, I primarily worked with Gulf sturgeon, but I was also involved in projects involving sharks, lionfish, striped bass, and juvenile fishes living within floating brown seaweed. I am 


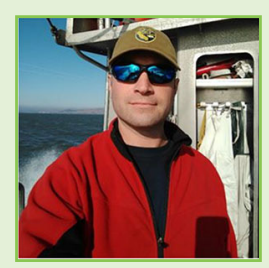

interested in ecology, behavior, and trophodynamics (feeding, food webs) of fish. I am especially interested how human alterations of habitat (pollution, engineered rivers, development) affect fish. * page.vick (anoaa.gov.

\section{JOHN T. KELLY}

Dr. John Kelly, CDFW. I am currently the statewide sturgeon coordinator for the California Department of Fish and Wildlife. I have always been interested in the behavior, physiology, and ecology of fishes. I started my career studying coral reef fish in Florida, and since then I have studied a wide range of species, including great white sharks, salmon, and sturgeon. I am interested in migration and movement, and especially interested in fish that move between fresh and saltwater. I first started studying sturgeon in 2000, when I was working on my Ph.D. at the University of California, Davis. *john.kelly@wildlife.ca.gov. 